\title{
Impacts of Syrian Crisis on Turkish-Iranian Relations: (Rojava Factor)*
}

\author{
Dr. Othman Ali \\ Assistant Professor, History department, University of Saladdin \\ Visiting Lecturer, Middle East Center: Sakarya University- Turkey \\ Email: kaurlaylan@yahoo.com
}

Zhirwan A. Ismail

Student of Master, Middle Eastern Study: Sakarya University-Turkey

Email: zhirwan.werty@yahoo.com

${ }^{*}$ The paper has been presented in the $4^{\text {th }}$ International Scientific Conference of University of Human Development- Iraq, April, 2017.

\begin{abstract}
The Syrian crisis in general and the Northern Syria (Rojava) cantons have a profound impact on Turkish-Iranian relations. We have a paradox here where the Kurdish factor seems to have initially driven Iran and Turkey a part and complicated the bilateral relations between the two countries. However, the Rojava factor has recently forced the two countries to some form of regional cooperation and in the future the desire of Turkey and Iran to prevent the emergence of a Kurdish entity in Northern Syria will be a strengthening factor for the bilateral relations. It is anticipated that Syrian and Iraqi regimes which share the same concern will join Turkey and Iran in this regional effort to contain or even destroy the Rojava experience. Nevertheless, the success of this regional effort will be dependent on the future of Russian and American stand towards Rojava.

In this paper, the factor of non-state actors in the current situation of the Middle East has been explained. The reasons of changing the traditional political map of the Middle East have been mentioned. Then specifically while talking about the Syrian crisis, Turkey and Iran have been focused on while they have been working for implementing their own political agendas in Syria. The impact of Syrian crisis in general on Turkish-Iranian relations has been explained. We then have particularly mentioned the rise of Rojava (the North Western part of Syria) as the main reason that affected the regional policies of Turkey and Iran. In the rise of Rojava, we have answered questions like who is supporting Rojava and why? Then we have proceed to explain and analyze the different views with which Iran and Turkey initially had about the emergence of Rojava Regime. Here in this stage, we have tried to give four main groups that have an effective role in the crisis. When we understand the nature of these groups, their antagonists and their supporters, we will almost understand the goals and interests of each main actor that supporting them including Iran and Turkey. Finally, we will reflect upon the Iranian ambitions and strategic goals in the region, taking Syria as an example, and why Turkey is trying to limit the hegemony of Iran.
\end{abstract}

Keywords: armed non-state actors, Middle East, Foreign Policy Analysis, Rojava, Kurds, Turkey, Iran

\section{Introduction:}

The Middle East currently experiences a number of nonestate actors which have armed power and have controlled specific areas as their territories. These none-state actors have become a challenge for the nation state system in the Middle East. This is because these actors have been able to control their territories, and peruse their foreign policy which is totally contradicting the nation state system policy. Scholars argue that we are in need of new paradigms for defining these non-state actors "as the state-centric Foreign Policy Analysis paradigms do not fit these actors". "Few clear examples of non-state actors that have recently affected the international politics and the international relations of the Middle East are the Kurds in both Syria and Iraq, the Islamic state and Hezbullah in Lebanon. ${ }^{2}$

"By their mere presence," Jossenlin and Wallace argue that "non-state actors can only flourish within a relatively peaceful and stable international system, with an underlying consensus about the rules of international interaction and the legitimacy of the state units." 3 These non-state actors do not only emerge within a dynamic time of the lack of state central authority but they also emerge in times of conflicts practicing their own authority by having their own militias available and controlling specific territories in particular areas. In these specific territories, these non-state actors totally peruse their own foreign policy within the particular controlled territory.

\footnotetext{
1 Van den Berge: "Analyzing Middle Eastern Armed Non-State Actors' Foreign Policy:" Leiden University, Institute of Security and Global Affairs: Summer 2016: Retrieved on June 16, 2017

2 Gunter M. Michael, "The Kurds and the Future of Turkey": The American Research Center Coalition, May 15, 1997. Retrieved on May 2, 2017.

${ }^{3}$ Van den Berge: "Analyzing Middle Eastern Armed Non-State Actors' Foreign Policy:" Leiden University, Institute of Security and Global Affairs: Summer 2016: Retrieved on June 16, 2017
} 
Rainer Baumann and Frank Stengel have mentioned in a literature review published in the Foreign Policy that attention for analyzing none-state actors have increased since 1990s in international politics. These two writers have noticed that most of international relations' scholars have stick to "traditional topics" while they do have noticed that none-state actors are included in some developments and analyses. Baumann and Stengel focus on the process of decision making and how the non-state actors are involved in the decision-making in the policy arenas. Furthermore, they continue asking how decision making in non-state actors is analyzed in different settings, how they are applicable and how they can be modified.

Considering the Middle East politics, we should ask questions like what has been the reason of weakening the political map of the Middle East? What has caused the too many changes, ups and downs, in the traditional political map of the region? Among other factors, there have been political, economic, military, and sociological factors being the reason of these changes in the region. These reasons can be totally applied for the change of traditional state system in Syria. In Syria, civil wars, and the absence of strong legitimate state institutions, and different motivations and interests have been the reason for changing the traditional state system. The Economist has recently concluded that "across the Middle East, non-state actors increasingly set the agenda, challenging governments, overthrowing them or prompting them to retrench behind increasingly repressive controls." ${ }^{1}$ Interestingly enough, some scholars have been arguing that in the Middle East there have been only two states have remained in the region which are Turkey and Iran. The others, they argue, including Syria, Kurds, Iraq, ISIS and etc can be defined as none-state actors of the region. ${ }^{2}$

\section{PKK in Turkish Iranian Relations before the Syrian Crisis:}

Right after the 1979 Islamic revolution of Iran, TurkishIranian relations normally experienced downturn. Turkey has accused Iran for supporting Islamic radical and fundamental groups opposing Turkey. However, the two countries still have managed economically cooperate and make good relations. Despite all that, there has been another very important issue between the two countries which is Kurdistan Workers Party (PKK). When the Turkish military operation started against PKK in Turkey and the North of Iraq, Turkey accused Iran for protecting PKK and providing them with full logistics and military support. Iran has been rejecting such accuses, however. While bombarding PKK military spots in the borders of Iran, these tensions increased between more. The tensions specifically increased in 1990s because Iran and PKK

\footnotetext{
${ }^{1}$ The Economist: "The Rule of the Gunman: Why Post-Colonial Arab States are Breaking Down:" Oct 11, 2014. Retrieved on April 13, 2017: http://www.economist.com/news/middle-east-and-africa/21623771-whypost-colonial-arab-states-are-breaking-down-rule-gunman

2 M Gunter " Iraq, Syria, ISIS and the Kurds: Geostrategic Concerns for the U.S. and Turkey:" The Middle East Policy Council. Retrieved on June 16, 2017: http://www.mepc.org/iraq-syria-isis-and-kurdsgeostrategic-concerns-us-and-turkey 571
}

relations during the 1990s have reportedly been strong. For example, in May 1995, the Turkish government conducted a very strong military attach on the PKK basis in the Iranian borders. And that bored Iran as well. In the spring of 1996, a number of crisis between the two countries happened when each of them accused the other for spying and supporting of terrorism. Yet, 1996 Turkey added another complain when PKK strongly attacked Turkish forces from the borders of Iran. The president of Turkey visited the borders and accused Iran for supporting terrorism. However, during his presidency between 1996 and 1997, NecmettinErbakan, leader of Islamic RefahPartisi (Welfare Party) made clear efforts to strengthen relations and cooperate with Iran to solve the issues. But he was meanwhile strongly criticized by public opinion in Turkey for visiting a country that supports "anti-Turkish terrorism."

Visits took place between the Turkish President to Iran and Iranian President Akbar Hashemi Rafsanjani to Turkey. But these visits could not decrease the concerns of both governments accusing each other. Later in 1996, the Turkish government continued accusing PKK of providing and supplying logistics and heavy military weapons including rockets of Katyusha. After that in 1997, the Iranian ambassador was embroiled by Islamic fundamentalists in Ankara, and that more deepened the tensions between the two countries. ${ }^{3}$

Relations subsequently between Iran and Turkey strengthened somehow. Leaders and decision makers of both countries were lunching different visits and exchanging ideas of cooperation. The most important cooperation was the "Neighborhood Forum" that took place in 1998. The forum was basically aiming for improving relations between the Middle Eastern neighbors. However, all there improvements could not solve or could not find a solution for the Turkish concern regarding Iran helping PKK logistically.

\section{The Turkish Foreign Policy and the Kurdish Question:}

Both countries, Turkey and Iran, in their regional competition have provided a space for Russia to become a player or broker between them because Russia has had better relations with both Turkey and Iran than Turkey and Iran have had between one another. Russia is openly practicing its strategic goals in Syria by providing full support for Assad's Regime while limiting Turkey's and Iran's roles in Syria not allowing them to take a step in Syria without Russia's approval. ${ }^{4}$ For example, only two weeks after the president of Turkey, Erdogan, visited Russian and had a meeting with Putin in August of 2016, "Operation Euphrates Shield" started. Ankara announced that the operation was an anti ISIS operation while it was mainly for limiting the Kurds in Syria to expand their controlled territory along the border of Turkey.

https://www.researchgate.net/publication/237734135_The_Kurdish_Questi on_and_Turkish_Foreign_Policy [accessed Jun 12, 2017

4 Friedman Brandon: "Russia, Turkey, and Iran: Cooperation and Competition in Syria." Retrieved on May 5, 2017: http://dayan.org/content/russia-turkey-and-iran-cooperation-andcompetition-syria 
Turkey and Iran in the Syrian Crisis:

The Turkish-Iranian relations have long history going back to Ottoman and Safavieh Empires in the region. In a survey of the historical bilateral of both countries, there are more conflicts than cooperation ones between the two countries. That is because both countries have been in great political and military competition for hegemony in the region. The rise of Arab Spring in the region in the second decade of the twenty first century can be seen as a remarkable historical stage that affected the strategic relations between Turkey and Iran. This is directly felt when we consider the Syrian crisis.

Since the start of revolts in Syria against Bashar al Asad in 2011, both countries, Iran and Turkey, have tried to maximize their power in the country. They have backed different groups and militias in Syria to gain their strategic goals. Despite of the fact that there is a common enemy which is the Islamic State of Iraq and Sham (ISIS), each of the countries, Iran and Turkey, has been supporting groups that harm the strategic goals of the other. For Turkey, the rise of Kurdish political identity in Syria is the red-line and must not happen because it would directly affect the Turkish national security. However, Iran has been the directing supporter of the Kurds in the country. With the help of Iran, Russia, and the US leading international coalition, the Kurds have been able to establish their political identity in the North of Syria naming the controlled region as Rojava. The riseof Rojava has been a serious concern for Turkey. From here, the rest of this paper will discuss the general impacts of the Syrian crisis on the Turkish-Iranian relations first. Basically the reasons that Turkey involved in the Syrian crisis will be explored. Then the humanitarian crisis in the country and how it has economically affected Turkey as the closest neighbor of Syria will be discussed. At the same time, the rise of the Kurds in Syria and to what extend this has relations with the Kurdish issue in Turkey will be explained. To what extent will the riseof Kurds in Syria would affect the Turkish national security? Another stage of this article is about the different political and military groups in Syria. Which main actor is supporting whom and which one is against whom in Syria is going to be focused on. The last stage of the paper will be about Iran's hegemonic strategies in the region especially in Syria. The main reasons that are importantly effective why Turkey involved the Syrian crisis to limit Iran's increasing hegemony in the region will be explained. ${ }^{1}$

North-Western Part of Syria (Rojava):

First of all, if we go back to the Turkish recent foreign policy especially within the start of Justice and Development Party (AK Party in Turkish) rule, it is clear that the AK Party wanted to change Turkish foreign policy in a way that it shifted its policy from the west to the east. That means the Middle Eastern countries, especially the neighbors, became the focus of Turkey to strengthen its political and economic relations with. The policy of "Zero Problems with Neighbors" was declared and implemented

${ }^{1}$ Serdar, Guner: "THE TURKISH-SYRIAN WAR OF ATTRITION: THE WATER DISPUTE:"

Studies in Conflict \& Terrorism, Jan-Mar 1997, Vol. 20 Issue 1, p105, p12 by the Turkish Government. It was successful for Turkey in a way that it enhanced the Turkish figure and the Turkish influence in the region. However, with erupt of the Arab Spring, practically speaking, the policy was died. That is because "zero problems with neighbors" mainly means zero problems with regimes of neighboring countries. And when there is democratic upheaval with these neighboring countries, it is clear that Turkey would not continue supporting these regimes at the time that Turkey is a NATO member and has an effective place in dealing with the international coalition regarding to the regional changes. ${ }^{2}$

Therefore, we can say that from the start of the Arab Spring, the "Zero Problems with Neighbors" has become a dead policy. Turkish standing against the Syrian Regime and its backing to the Sunni oppositions of Syria against the regime is a clear example showing the end of Zero Problem's policy. There have been new strategic goals and security problems that are more important for Turkey regarding to the Syrian Crisis.

The rise of the Kurds in Northern Syria is one of the serious problems about which Turkey is concerned. In the Northern Syria, the Kurdish Area that has been controlled by the Democratic Union Party (PYD) which is a branch of Kurdistan Workers Party (PKK) in Syria, is known as Rojava. Rojava is consisted of three cantons and has declared its autonomy. The cantons of Cizire, Afrin and Kobani are the three cantons each of which is an autonomous canton through the federalist system that was declared by PYD in March 17, 2017 under the name of "Democratic Federal System of Northern."

In order to have a better understanding of the context of Rojava, we would like to give a brief background about each of the three cantons. The population of Cizire Canton is about 1,600,000 and it declared its autonomy in January 21st of 2014. Afrin Canton's populations is approximately more than one million, and it declared its autonomy in January 29th of 2014. Kobani Canton is populated between 350 and 400 thousand and it declared its autonomy in January 27th of 2014. The total population of all Rojava cantons was 2.5 million people before. However it has increased to 4.6 million people by 2015 , according to a NYT report titled as "A Dream of Secular Utopia in ISIS Backyard"3. The total surface area of the land that is under the PYD control is 18,300 square kilometers. And the capital of Rojava is Qamishlo (Qamislo).

In terms of military groups, the major military group in Rojava is People's Protection Units (YPG) which is the military branch of PYD. The number of their fighters were 60,000 militias by the end of 2016. In 2017, YPG added other 10 new battalions which each consisted about 300 fighters. And they are now planning to exceed 100.000 fighters by the second half of $2017^{4}$

\footnotetext{
${ }^{2}$ Interview with SinanUlgen, 2011: ““'Policy of Zero Problems with Neighbors Successful for Turkey." CARNEGIE EUROPE: Retrieved from http://carnegieeurope.eu/2011/12/18/policy-of-zero-problems-withneighbors-successful-for-turkey-pub-46280

${ }^{3}$ Enzinna, Wes: "A Dream of Secular Utopia in ISIS Backyard." Retrieved from: https://www.nytimes.com/2015/11/29/magazine/a-dreamof-utopia-in-hell.html? $\mathrm{r}=0$

${ }^{4}$ Dolamari, Mewan: "Syrian Kurdish YPG will increase number of fighters to 100,000 in 2017." K24, March 21, 2017. Retrieved from:
} 
Now, who is supporting PYD and why? This is the main question that is going to give us details for our focus of the subject. By answering this question, we will understand the whole picture of the regional competition between Iran and Turkey, and we will understand where the tensions start in Syrian crisis. The first actor that is supporting PYD in Rojava is the United States of America (USA). The USA is helping PYD for many reasons. The most important one is that PYD has been seriously fighting against ISIS, and defeating ISIS is the main focus of the USA in the region. Second, YPG has been the most organized and internally united military group among the other military groups of Syria. Next, securing oil resources in the near future in Rojava that is now controlled by PYD is also another reason that now the USA helping PYD. Furthermore, PYD is a non-religious secular group, which is really essential for the USA because the US is more likely to help secular groups against radical religious ones. ${ }^{1}$

The second actor that is openly supporting PYD in Rojava is the International Coalition forces which is known as Combined Joint Task Force - Operation Inherent Resolve (CJTF - OIR) consisted of 30 countries led by the USA. The same reasons that mentioned above generally might be applied for explaining why the International Coalition helps PYD. However, each country that has a hand in the International Coalition has its own interests and goals. For example, France is helping the Kurds because it seems that it does not want to repeat the mistakes of the past that it made in the region. After the WW1, France had a huge impact in dividing the borders of the Middle East. In that division of borders, no place was provided for the Kurds who have been more than 50 million people sharing their own cultural and traditional characteristics like other nations in the region. Now, the same picture of post WW1 seems to be repeated to be drawn again. Therefore, France does not want to repeat its mistakes in the region because giving to the Kurds their own independent land seems to be a better choice in order to solving the regional issues in the right way. ${ }^{2}$

Moreover, Russia is also another actor that helps PYD in Rojava. The reasons that Russia is helping them is that, same as the US, they have a common enemy which is ISIS. PYD is also used as a card by Russia while dealing with Turkey. That is, when on November 24, 2015, Turkey shot and downed a Russian warplane on the Turkish-Syrian border, there was a high claim in the Kurdish community that Russia is going to support the Kurds in Northern Syria

http://www.kurdistan24.net/en/news/ad2a1bc1-ffb8-4253-9f65213c8add1 fa3/Syrian-Kurdish-YPG-will-increase-number-of-fighters-to100-000-in-2017

I. ${ }^{1}$ MALSI, JARED: "U.S. ARMING OF SYRIAN KURDiSH Militias COULD Complicate Relations With TURKey.” TME: May 2017: Retrieved FROM: HTTP://TIME.COM/4773999/TURKEY-YPG-ARMING-MILITIASDONALD-TRUMP/

II. "Rudaw: "AN Iranian Solder Killed IN Syria." HTTP://WWW.RUDAW.NET/SORANI/MIDDLEEAST/SYRIA/02062017 to take revenge on Turkey. And Russia has also supported the Federalist System that now has been announced by the Kurds in Syria, with the claim that Kurds should not ask for toppling down the regime of Assad. ${ }^{3}$ At the same time, Russia has openly trained the YPG forces militarily in Rojava, for example in Afrin Canton.

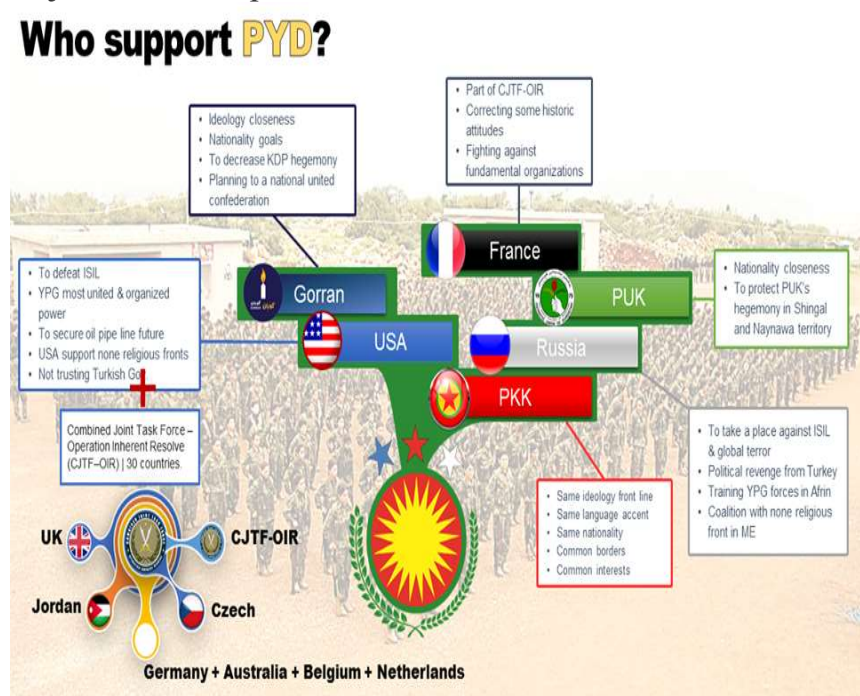

Figure 1: Who is supporting PYD in Syria?

There are a lot of other local and international actors supporting PYD in Syria, as it is shown in the figure 1. No need to be mentioned, PYD is ideologically and militarily a branch of PKK, a fact that is denied by some. PKK and PYD have the same ideology, same language dialect, same nationality, common borders and common interests. At the same time, in terms sociobiological aspects, the Kurds in Syria are closer to the Kurds in Turkey than being close to the Kurds in other parts of Iraq and Iran. The Turkish and Syrian Kurds have historical cultural interactions. When there were clashes in Kobani, late 2015, there were reportedly hundreds of Kurdish young people in Turkey illegally crossed the border and went to defend the Kurds in Syria. $^{4}$

PYD at the same time is supported by Kurdish political parties in the Kurdistan Region of Iraq, especially being very close to Patriotic Union of Kurdistan (PUK) and Gorran Movement. PUK is simply supporting PYD to protect its hegemony in Shingal and the areas of Nainawa, which are partly controlled by PKK. At the same time, they share the same nationality and ideological closeness. Moreover, one of the goals of Gorran Movement in the Kurdistan Region, according to their official platform is to build a national united confederation. PKK and PYD are ideologically very close to Gran movement, and they have the same left wing ideology. They both, Gorran and PKK, share the same nationality claim. Most importantly, Gorran recently has issues and misunderstandings with Kurdistan Democratic Party (KDP) on governmental and

\section{3“'SYRIAN KURDS SAY RUSSIA TO BUILD BASE IN AFRIN.” AL JAZEERA: RETRIEVED FROM: \\ HTTP://WWW.ALJAZEERA.COM/NEWS/2017/03/RUSSIA-STRIKES-DEAL- SYRIAN-KURDS-SET-BASE-170320142545942.HTML}

\footnotetext{
${ }^{4}$ The Kurdish Project: "YPG: People's Protection Units Profile." Retrieved from: http://thekurdishproject.org/history-and-culture/kurdishnationalism/peoples-protection-units-ypg/
} 
administrational issues in the Kurdistan Region. Gorran is supporting PYD in Rojava and PKK in Shangal and the areas of Nainawa so that to decrease KDP's hegemony in that areas.

All the above mentioned actors are supporters of PYD in Rojava. But what we have not talked about yet is Iran. Iran is strongly backing the Syrian Regime of Assad. And PYD is reportedly supported by Assad, and they have good relations together. If we look at the map of Rojava, the cantons of Kobbani and Afrin are separated from each other since Turkey has controlled Jarablus. There is no way for PYD to go to Afrin Canton unless they have relations with the regime of Syria and go through the areas of Aleppo. I have personally interviewed many people who have fled from Rojava and settled down in the Kurdistan Region refugee camps that "PYD is strongly depended on the Syrian Regime" which means PYD is strongly backed by Iran too. Despite of that, PKK has good relations with Iran, and it gets military and logistic help from Iran, especially since the start of the second decade of the twenty first century.

These help of Iran and the other states has seriously made Turkey take steps against the rise of the Kurds in Rojava. Turkey has worked hard to force the international community not to help PYD and the Kurds in Syria. Turkey has been repeatedly arguing that for them there is no difference between PYD and ISIS. They have even recently taken actions by bombarding them with airstrikes in the areas of Sijar in Iraq and Derk in Syria, in the borders of Syran and Iraq.

\section{Different Militia Groups in Syria:}

If we look at the whole picture of Syria, we can see many different military groups which each is supported by different main actors. Here we would like to introduce four different main groups, their supporters and their antagonists to better understand the whole situation of Syria. We have chosen four main and the most important groups. The first group is YPG which we have been talking about. YPG is the military branch of the Syrian Kurdish Democratic Union Party PYD. YPG is currently one of the largest factions in the Syrian civil war and was the first group in the country to win the largest scale battle against ISIS. The group has been able to win and control all the North-Western part of the country, which is known as Rojava.

The General Commando of YPG is SipanHamo. And it is helped by many actors as mentioned above. The antagonists of YPG are Turkey, the Free Syrian Army, and ISIS.

The second group from the most important military groups in the Syrian crisis is the main opposition group which is known as the National Coalition of Syrian Revolution and Opposition Forces, it is also known as NC. The group is acting as a transition or interim government of the country. The NC has been founded in 2012 as the second attempt by the international community to create an organization that represents the whole Syrian people since the Syrian National Council (SNC) failed in this regard. ${ }^{1}$

\footnotetext{
${ }^{1}$ National Coalition of Syrian Revolution and Opposition Forces: Official Website, http://en.etilaf.org/about-us/goals.html

The president of the organization (NC) is Muhammad AlAbde who has full executive powers within the organization. The group has an executive branch in Idlib (Syria). And it is backed by the USA and among the regional countries, Egypt is strongly backing the group.

Another group that has a very effective role in the Syrian crisis is JabhatFateh Al-Sham or Jabhat Al- Nusra. This group is the most dangerous group in Syrian crisis. It is a Sunni terrorist organization that aims to establish an Islamic Emirate in Syria by overthrowing the Assad Regime. This group was founded in 2011 when Al Qaeda in Iraq (AQI) sent its members from Iraq to Syria to expand its regional cells. However, the group has officially declared its existence from Al Qaeda since 2012. ${ }^{2}$ The ideology of the group is an Islamic extreme ideology claiming for the establishment of an Islamic State in Syria governed by their own interpretation of the Islamic Law.

The current leader of the group is Abu Muhammad alJulani. Many Islamic radical groups are backing Jabhat AlNusra, such as, Ahrar al-Sham, Ferliq al-Sham, Aynad alSham Front (SRF), Jaysh al-Sunnah, al-Haq Brigade, and Jund al- Aqsa. However, its direct antagonists are the USA and allies, the Syrian Regime, the Syrian revolutionary, and HarakatHazzm.

The last group that has an effective role in the Syrian crisis we want to mention is the Syrian Democratic Forces (SDF). The SDF is a coalition of various armed militias with the largest groups being Kurdish, Arab, Assyrian, Armenian, Turkmen, and Chechen backgrounds. This coalition is the official defense force of the Democratic Federal System of Northern Syria (Rojava). The coalition was founded in October 2015 when the YPG started to assimilate other opposition forces around the territory of ISIS and the Syrian government. The SDF is viewed by the Turkish Government as a branch of PKK. Therefore, Turkey sees the coalition as a terrorist organization. However the US and the international coalition deals with the organization as their best ally on the ground in fighting ISIS. ${ }^{3}$ TelalSelo is the official spokesman of the group and acts as a bridge between the group and its supporters.

\footnotetext{
${ }^{2}$ BBC News, Middle East: "Syria war: Who are JabhatFateh al-Sham?" August 2016: Retrieved from: http://www.bbc.com/news/world-middle$\frac{\text { east-36924000 }}{3 \text { Lund Aron: }}$

${ }^{3}$ Lund Aron: "Origins of the Syrian Democratic Forces: A Primer: Retrieved from: https://www.newsdeeply.com/syria/articles/2016/01/22/origins-of-thesyrian-democratic-forces-a-primer
} 


\section{- Syrian Groups}

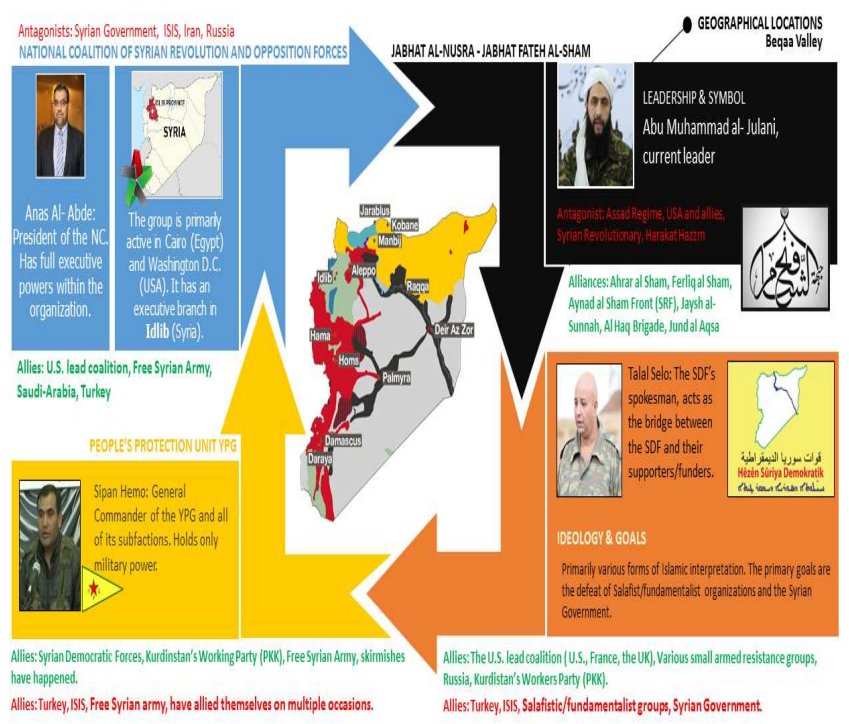

Figure 2: Different Militia Groups of Syria

As it is exposed above, from these different ideological and militia groups, the Syrian crisis has been much more difficult to solve. That is because if we look at the whole picture of the crisis, we can find that each group is backed by a different actor and each actor has its own goals and interests in the country which contradicts the others' goals and interests. The result of these crisis has brought a fatal humanitarian crisis in the country. Millions of people and children have lost their lives and many others have fled to other countries.

\section{Humanitarian Crisis in Syria:}

We would like to shortly give some data on the humanitarian crisis in Syria since 2011. According to Violation Documentation Center Syria, number of people being killed in Syria since 2011 is 170,480 people, listed and recorded with full name. ${ }^{1}$ However, Staffan de Mistura late in 2016 once has said that the total people killed in the crisis are about 400,000 victims. According to data recorded by the United Nations Office for the Coordination of Humanitarian Affairs (UNOCHA), number of total explosions in the Syrian Crisis is 5751 explosions. There have been 10024 fire executions, 34747 shelling, 54490 shooting, 2147 kidnapping- execution, and 30571 warplane shelling. This is all since late of 2016 recorded by UNOCHA. ${ }^{2}$

${ }^{1}$ Violation Documentation Center in Syria (VDCS): $\underline{\text { http://vdc- }}$ sy.net/en/

${ }^{2}$ UNOCHA data on Syrian Crisis: http://www.unocha.org/country/syrian-arab-republic/syria-countryprofile/syria-country-profile 575
According to: Recorded with full name

Violation Documentation Center Syria

Total victims in Syria, Latest Killed 170/80

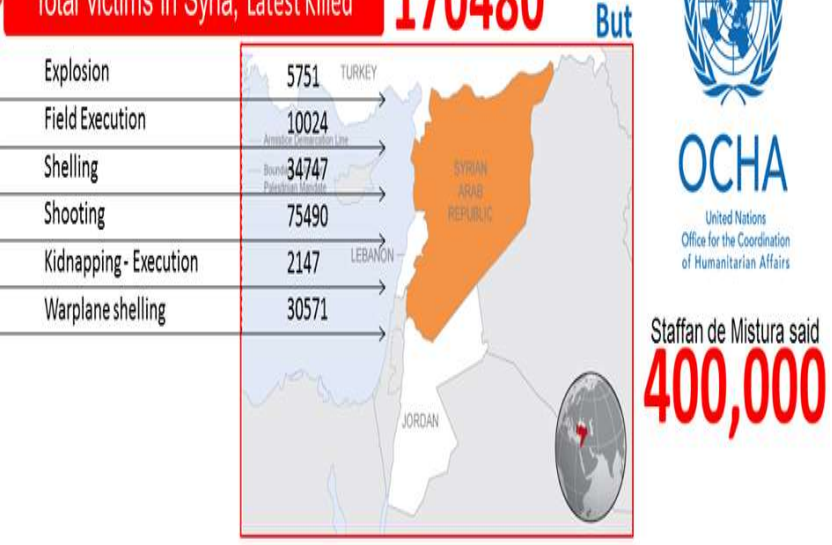

Peoplein need of humanitarianassistance

Mar: 2012 1000,000

Mar. 2017 13,500,000

People internalydisplaced byviolence

Jan. $20132,000,000$

Mar, $20176,325,978$

Peoplewhofled the country Mar: 2012 21,959

Figure 3: Humanitarian Crisis in Syria, Source: (OCHA)

As it is shown in the above figure, in March 2012, about 1000,000 people were in need of humanitarian help in Syria. However, by March 2017, there are about $13,500,000$ people in need of humanitarian help. People who fled the country in March 2012 were 21,959 people while this number has increased to $5,020,470$ people by March 2017. Moreover, number of people internally displaced (IDP) by violence was 2,000,000 while the number has increased to $6,325,978$, according to data from the UNOCHA. ${ }^{3}$ This humanitarian crisis is very important while we are talking about the effect of the crisis on Turkey and Iran because Turkey as the closest neighbor of Syria has been very much affected by the crisis economically and politically. The number of Syrian refugees in Turkey has been 2,992,567 people, according to data from the UNHCR last updated in April 27, 2017. ${ }^{4}$ This huge number of refugees has left negative socioeconomic effects on Turkey. This is one of the important reasons that Turkey has involved in the Syrian crisis and wants to solve the crisis in a way that in the future Turkish political and economic interests will not be under threat in the region.

\section{Iran's Hegemonic Ambitions in the Region:}

Iran has a number of ambitions in order to strengthen its hegemony in the region. And Syria is one of the most important countries that has been the center of Iranian strategic ambitions in the region. Turkey, as an important actor of the region, definitely would take actions and compete for pushing back the Iranian strategy in the region. Iran has developed a formidable presence on the ground of

\begin{tabular}{l}
$\begin{array}{l}{ }^{3} \text { UNOCHA } \\
{ }^{4} \text { UNHCR } \\
\text { http://data.unhcr.org/syrianrefugees/regional.php }\end{array}$ \\
\hline
\end{tabular}


Syrian crisis. Iran has simply penetrated the Assad Regime's remaining institutions. For example, it has embedded about 30,000 ground forces in the government controlled areas of western Syria (about 5,000 IRGC, Basij, and Iranian Army elements). Moreover, there have been about 3,000 to 5,000 highly trained Hizbollah fighters brought to Syria from Lebanon. At the same time, there have been around 20,000 Shiite militiamen being returned from Pakistan and Afghanistan to support the Assad Regime in Syria. ${ }^{1}$ Reportedly, so far up until May 2017, there have been 2,200 members of the Iranian Army killed in the recent instabilities of Syria and Iraq. ${ }^{2}$ This is all despite of the huge logistic help of Iran to the Assad Regime. Iran has backed the Syrian Regime at a time that Turkey has strongly worked for toppling down Assad and claimed for regime change in Syria. Therefore, Turkey has stepped to stop and limit the Iran's hegemonic power in the country.

Moreover, there are a lot of other aspects showing Iran's interests to increase its hegemony in the region. These aspects can become the indirect reasons for Turkey standing against Iran in Syria because at the end Iran would change its regional balance with Turkey. One of these aspects is the Iran's rigorous enforcement of its nuclear policy that is something Turkey is not happy with because this will strengthen Iran's hegemony in the region and change the regional balance between Turkey and Iran. Another reason that Turkey has stood against Iran in Syria is that Turkey does not want Syria to become the second Iraq for Iran's hegemony. What we mean here is that Iran after 2003, has almost controlled all the essential powers and institutions of Iraq, and this has decreased the hegemony of Turkey in the country. Therefore, it is neither easy nor is it achievable for Turkey to eliminate Iran's power in Iraq. Therefore, concerning the Syrian crisis, Turkey seems that does not want to repeat the same mistakes it has done in Iraq. At least it wants to make its borders safe and limit the rise of Kurdish political identity in the North of Syria because that will directly affect its national security.

\section{Conclusion:}

The Middle Eastern traditional political map has recently faced changes due to the challenge of non-state actors inside particular territories of sovereign states. Kurds in Northern Syria (Rojava) are clear examples of these non-state actors that have affected the regional developments. Turkey and Iran are the two sole countries that some scholars argue that remained as total healthy states of the region. These two countries, Turkey and Iran, have been in regional competition in Syria. The rise of Rojava has directly affected Iranian and Turkish interests in the region. For

IV. ${ }^{1}$ DEHGHANPISHEH, BABAK: "IRAN RECRUITS PAKISTANI SHI'ITES FOR COMBAT IN SYRIA.” REUTERS: RETRIEVED FROM: HTTP://WWW.REUTERS.COM/ARTICLE/US-MIDEAST-CRISIS-SYRIAPAKISTAN-IRAN-IDUSKBNOTT22S20151210

\footnotetext{
${ }^{2}$ Iddon, Poul: Will Paris atrocity foster stronger French-Kurdish cooperation against ISIS?" Rudaw Analyses: Nov 2015. Retrieved from: http://www.rudaw.net/english/analysis/15112015 576
}

Turkey, having a particular territory controlled by the Kurds in Northern Syria is a serious concern because it is a danger for the Turkish national security. However, Iran and the Kurds in Syria have been in good relations and Iran is reportedly providing the Kurds military and logistics support. Kurds in Rojava as non-state actors are now owning their military forces and practicing their own foreign politics with controlling particular territory inside Syria. 
References:

BBC BBC News, Middle East: "Syria war: Who are JabhatFateh al-Sham?" August 2016: Retrieved from: http://www.bbc.com/news/world-middle-east-36924000

I. DEHGHANPISHEH, BABAK: "IRAN RECRUITS

PAKISTANI SHI'ITES FOR COMBAT IN SYRIA.” REUTERS: RETRIEVED FROM: HTTP://WWW.REUTERS.COM/ARTICLE/USMIDEAST-CRISIS-SYRIA-PAKISTAN-IRANIDUSKBN0TT22S20151210

Dolamari, Mewan: "Syrian Kurdish YPG will increase number of fighters to 100,000 in 2017." K24, March 21, 2017. Retrieved from: http://www.kurdistan24.net/en/news/ad2a1bc1-ffb8-42539f65-213c8add1 fa3/Syrian-Kurdish-YPG-will-increasenumber-of-fighters-to-100-000-in-2017

Enzinna, Wes: "A Dream of Secular Utopia in ISIS Backyard." Nytimes, 2015. Retrieved from: https://www.nytimes.com/2015/11/29/magazine/a-dreamof-utopia-in-hell.html?_r=0

Friedman Brandon: "Russia, Turkey, and Iran: Cooperation and Competition in Syria." Retrieved on May 5, 2017: http://dayan.org/content/russia-turkey-and-irancooperation-and-competition-syria

Gunter M. Michael, "The Kurds and the Future of Turkey": The American Research Center

Iddon, Poul: Will Paris atrocity foster stronger FrenchKurdish cooperation against ISIS?" Rudaw Analyses: Nov 2015. Retrieved from: http://www.rudaw.net/english/analysis/15112015

Interview with SinanUlgen, 2011: ““"Policy of Zero Problems with Neighbors Successful for Turkey." CARNEGIE EUROPE: Retrieved from http://carnegieeurope.eu/2011/12/18/policy-of-zeroproblems-with-neighbors-successful-for-turkey-pub-46280

Lund Aron: "Origins of the Syrian Democratic Forces: A Primer: Retrieved from: https://www.newsdeeply.com/syria/articles/2016/01/22/orig ins-of-the-syrian-democratic-forces-a-primer

Malsi, Jared: "U.S. Arming of Syrian Kurdish Militias Could Complicate Relations With Turkey.” TME: May 2017: Retrieved from: http://time.com/4773999/turkey-ypgarming-militias-donald-trump/

M Gunter " Iraq, Syria, ISIS and the Kurds: Geostrategic Concerns for the U.S. and Turkey:" The Middle East Policy Council. Retrieved on June 16, 2017 : http://www.mepc.org/iraq-syria-isis-and-kurds-geostrategicconcerns-us-and-turkey

National Coalition of Syrian Revolution and Opposition Forces: Official Website, http://en.etilaf.org/about-us/goals.html
RUDAW: “AN IRANIAN SOLDER KILLED IN SYRIA."
2017.

HTTP://WWW.RUDAW.NET/SORANI/MIDDLEEAST/SYRIA/0206 $\underline{2017}$

Serdar, Guner: "THE TURKISH-SYRIAN WAR OF ATTRITION: THE WATER DISPUTE:"

Studies in Conflict \& Terrorism, Jan-Mar 1997, Vol. 20 Issue $1, \mathrm{p} 105, \mathrm{p} 12$

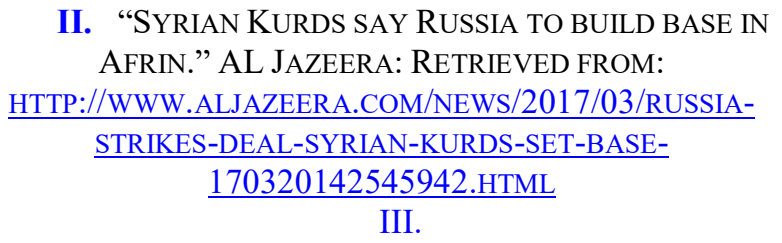

II. "SYRIAN KURDS SAY RUSSIA TO BUILD BASE IN AFRIN.” AL JAZEERA: RETRIEVED FROM: HTTP://WWW.ALJAZEERA.COM/NEWS/2017/03/RUSSIASTRIKES-DEAL-SYRIAN-KURDS-SET-BASE170320142545942.HTML

III.

The Economist: "The Rule of the Gunman: Why PostColonial Arab States are Breaking Down:” Oct 11, 2014. Retrieved on April 13, 2017: http://www.economist.com/news/middle-east-andafrica/21623771-why-post-colonial-arab-states-arebreaking-down-rule-gunman

Van den Berge: "Analyzing Middle Eastern Armed Non-State Actors' Foreign Policy:" Leiden University, Institute of Security and Global Affairs: Summer 2016: Retrieved on June 16, 2017 